\title{
CONSERVATION OF TRADITIONAL SETTLEMENT PATTERN IN 3-4 ULU SUB-DISTRICT PALEMBANG CITY
}

\author{
Nyimas Atika Marwiyah Muthmainah ${ }^{1 *}$, Wara Indira Rukmi ${ }^{2}$, Chairul Maulidi ${ }^{3}$ \\ ${ }^{1.2 .3}$ Department of Urban and Regional Planning, Engineering Faculty, University of Brawijaya, \\ Mayjen Haryono Street No. 167, Malang 65145 Phone (0341)567886 \\ *Corresponding author; E-mail: nyimasatikamm@gmail.com
}

\begin{abstract}
Traditional settlements in the 3-4 Ulu Sub-District are located on the outskirts of the Musi River, Palembang City. There are problems in traditional settlements including new buildings currently covering traditional buildings and not adjusting the old building shape as well as socio-cultural and economic. The purpose of this study was to identify physical and non-physical characteristics as input in a descriptive analysis that will produce a type of settlement pattern and further determine the conservation strategies. The method used is descriptive. Descriptive analysis illustrates the condition of the region including the history of the development of settlements, of social economic activities and culture of family violence, physical buildings and Outstanding Universal Value. Based on the results of the study, the overlay between physical and non-physical characteristics revealed that there were three settlement patterns in the 3-4 Ulu Sub-District. In each type of settlement pattern will carry out conservation strategies including preservation, conservation, rehabilitation, and reconstruction.
\end{abstract}

Keywords: Traditional settlements; settlemen patterns; conservation.

\section{INTRODUCTION}

In general, the edge of the river is one of the locations of choice for settlements, especially traditional settlements. Population growth and development as well as changes in the level of village position in government structures have an influence on traditional settlements that will become cities, especially in the administrative capital which was once the residence of a king or sultan (Rahmadi in Cesain, 2015). The administrative capital has a problem related to the limited availability of land for settlements, while the demand for shelter needed by the community is very high because shelter is a basic human need as shelter, sleep, rest and gather with family (Permatasari, Antariksa, \& Rukmi, 2008). in addition, urban areas have limitations in the availability of housing to increase housing space, so people in urban areas must adapt to these conditions (Asikin, Antariksa, Wulandari, \& Rukmi, 2017). One of the cities in Indonesia that has natural river conditions and experiences the history of this development is the city of Palembang. The city of Palembang has the Musi River which divides Palembang City into two parts, namely Seberang Ilir in the north and Seberang Ulu in the south. There are several traditional settlements on the edge of the Musi River which are currently one of the tourist attractions and a cultural preserve in the city of Palembang. Besides that the city of Palembang has passed three periods of government, namely the reign of the
Palembang Darussalam Sultanate, the Dutch colonial period and the Japanese colonial period (Lussetyowati, 2012).

One of the original traditional settlements of Palembang that still exists today is in 3-4 Ulu SubDistrict, Seberang Ulu I District, Palembang City. Traditional settlements are often represented as places that still hold customary and cultural values that relate to beliefs or religions that are specific or unique to a particular society rooted in a particular place and are beyond historical determination (Sasongko, 2005). According to Sasongko (2005), that the spatial structure of settlements described by identifying a place, the track, the boundary as a main component, further oriented through the hierarchy and network, which appear in a built environment may be physical or non-physical that would benefit not only the orientation but also the real object from identification. This traditional Palembang native settlement is a settlement that follows the development of the era of the Palembang Darussalam Sultanate to the current government. The location of this settlement is on the outskirts of the Musi River. Traditional settlements native to Palembang in 3-4 Ulu Sub-District have traditional buildings such as Rumah Limas, Rumah Cara Gudang and Rumah Rakit, but some new buildings began to cover the old buildings (Lussetyowati, 2012).

New buildings do not adjust the shape of buildings with old buildings. Traditional houses such as Rumah Limas, Rumah Cara Gudang and Rumah 
Rakit in settlements in 3-4 Ulu Sub-District are currently lacking maintenance from the government, especially buildings located on the edge of the river are less organized. Residents living in traditional settlements consist of indigenous inhabitants of Palembang City and immigrants from outside the city of Palembang, this condition can threaten the social, cultural and economic activities of the people in traditional settlements. As in traditional settlements in Bali, it is also threatened by urban development, one of which is the aspect of livelihood changes and the presence of foreign residents who cultivate rice fields into villas or hotels (Maulidi \& Wulandari, 2017). Based on the explanation of the problems of traditional settlements in 3-4 Ulu Sub-District, it would require a study to identify physical and non-physical characteristics, knowing the traditional settlement patterns and determine the shape of the preservation of the traditional settlements.
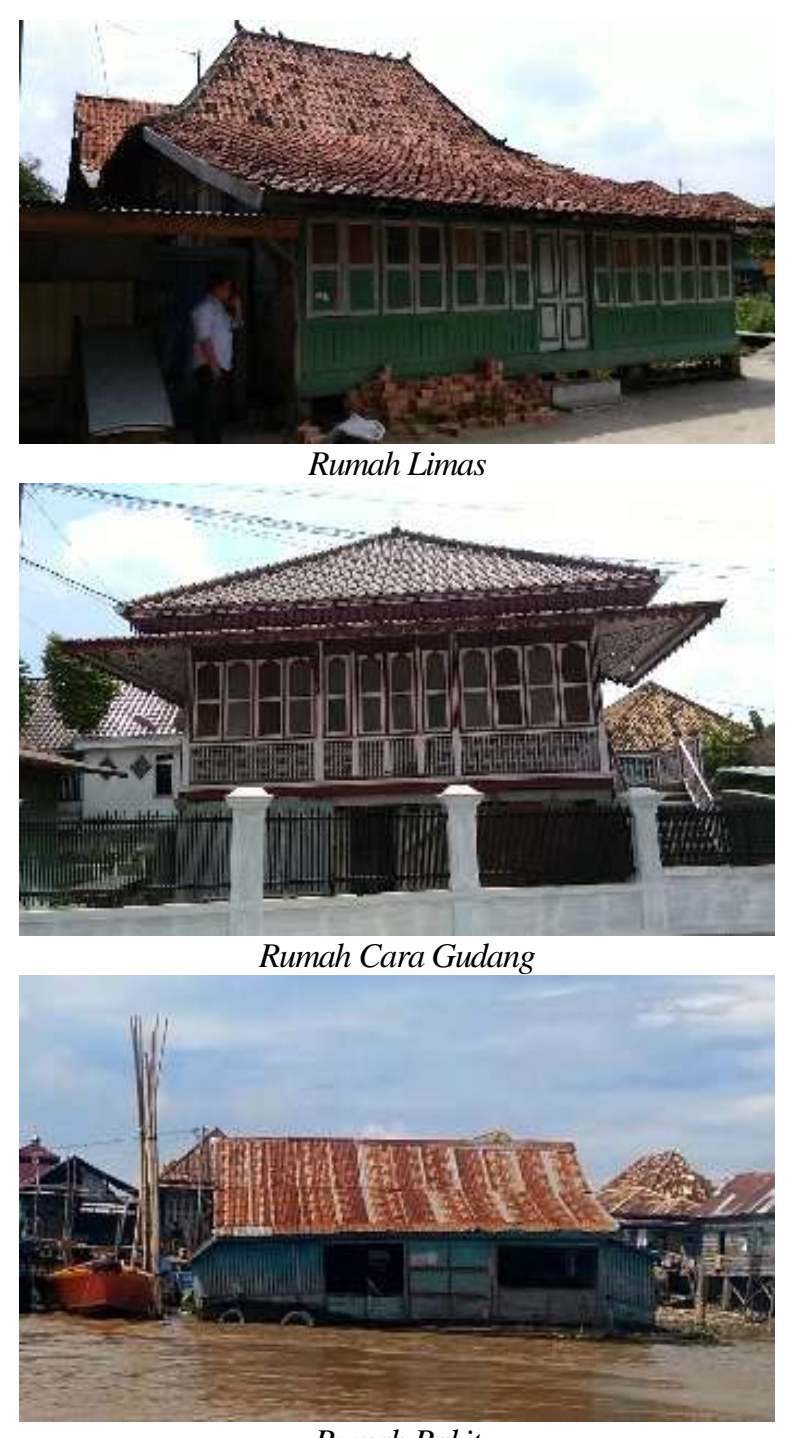

Rumah Rakit

Fig. 1. Traditional Buildings in 3-4 Ulu Sub-District

\section{METHODOLOGY}

Methods for the preservation of traditional settlement patterns using descriptive methods. The type of settlement pattern is the type of settlement pattern that has been generated from map analysis (overlay) by using physical characteristics (the building of houses, rivers, swamps, roads and shared yard) and nonphysical characteristics (socio-cultural, economic, and family relationships) map data. The method of data collection in this study was carried out in two ways, namely primary survey and secondary survey. In the primary survey conducted field observations on the object of the research and conducted interviews with respondents who had been sampled. Secondary surveys conducted surveys in agencies and literature studies. The sample technique used is purposive sampling, this technique is one of nonrandom sampling by selecting samples based on the criteria needed to solve the problem. So it was found that the physical conditions included the building of houses, rivers, swamps, roads and shared yard and as many as 75 families that would be used as research samples. The type of settlement pattern is the type of settlement pattern that has been generated from map analysis (overlay) by using physical and non-physical characteristics map data. Overlay analysis using a computerbased geographic information system. Geographic information system are able to analyze statistical data and overlays or called spatial analysis. Spatial analysis is to use two maps which are stacked to produce a new map from the overlay (Handayani, Soelistijadi, $\&$ Sunardi, 2005).

\section{RESULTS AND DISCUSSION}

\section{Type of Settlement}

The type discussion will explain the condition of the river, swamps, roads, shared yard, building layout, building type, history, cultural customs, economy, and kinship in each type of traditional settlement pattern and then explain the physical and non-physical linkages. After overlaying all maps on physical and non-physical characteristics, three types of settlements were found.

There are three types found based on the results of map overlays on physical and non-physical conditions (see figure 1). In Type 1 it was found that there were roads, shared yard, Rumah Limas, Rumah Cara Gudang, and Dutch colonial house. The pattern formed in this type is a cluster based on family relationships, so that it forms like a family complex. The family complex is inhabited by descendants of $\mathrm{H}$. Akil (the first figure to set up a Rumah Limas in a traditional settlement). H. Akil is a native of Palem- 
bang who worked as a big merchant during the Palembang Darussalam Sultanate by establishing a company called Firm H. Akil, so it can be concluded that the population in Type 1 is a native of Palembang descent. Social cultural activities in Type 1 have 4 types of activities including wedding ceremonies, ngunting, ngobeng, and death events. All of these activities are still implemented by the family of Firm $\mathrm{H}$. Akil. The majority of economic activities in Type 1 are traders who become well-known entrepreneurs in the city of Palembang and trade in traditional settlements. The relationship between physical and nonphysical links are found that:

- The condition of building management is influenced by kinship.

Based on the findings, the residents of the Rumah Limas who are native to Palembang as well as the descendants of $\mathrm{H}$. Akil form a group pattern by making their own complexes specifically the descendants of the $\mathrm{H}$. Akil family with identity using small gates. The determination of the location for a house inhabited by H. Akil's family is influenced by the rules of the parents, namely the Rumah Limas which is made to lead to the parent's pyramid house or to be next to the parents' house or a relative of $\mathrm{H}$. Akil. So with this policy, the special pattern of $\mathrm{H}$. Akil's descendants has become a cluster. Kinship relations in traditional settlements affect the shape of the house, especially in the native people of Palembang. In the family tree analysis, it was found that the occupants who were still related by the family of $\mathrm{H}$. Akil had the same house shape, the Rumah Limas.

- Type of building affected by natural conditions.

- Building types are influenced by social culture.

- Road networks are influenced by social culture.

Type 2 is the area of immigrants from outside the city of Palembang with the type of stilt house building on swamp land. The type of road pavement in Type 2 mostly uses cement and wood pavement. The pattern formed in Type 2 is linear with orientation to the road in the Hall of the Firm H. Akil and Lorong Hijriyah. The stage buildings behind the H. Akil Firm complex began in the 1950s, at that time there were still lots of vacant land in the form of swamps so that migrants were interested in building houses in the swamp area to date. The relationships between physical and non-physical in Type 2 are found that:

- The condition of wood and cement roads that are made like the shape of a connecting bridge is influenced by natural conditions, namely swamp land.

- Natural conditions are influenced by social culture.
These two aspects are interrelated between community activities and swamps. The swamps are used by the community to carry out socio-cultural activities including Palembang's traditional wedding and death events. The economic activity that uses swamps is manufacturing Palembang's special food, namely Kemplang. In the condition of socio-cultural activities, usually families who are making a celebration or traditional activities in their house and not enough to accommodate the invited guests, the celebration owner utilizes additional space by using the swamp land as an additional so that it requires additional tents and a stage. In economic activities, the community with swamp land is functioned as a drying area for processed food located behind the home of the business owner.

- Pathways are influenced by social culture.

- Type of building affected by natural conditions.

- Type of building influenced by kinship.

- The relationship between building arrangements, roads, is influenced by kinship.

Type 3 is located on the outskirts of the Musi River which is inhabited by migrants with a type of Rumah Rakit oriented to the Musi River. Rumah Rakit is the remainder of the traces of civilization during the Palembang Darussalam Sultanate. Rumah Rakit that are still in traditional settlements, especially Lorong Hijriyah 3-4 Ulu Sub-District consist of 2 housing units. The traditional activities that are applied to Type 3 are only weddings from Palembang's original wedding ceremonies and death events. Social cultural activities will be carried out in family homes on the mainland. The livelihoods of the people in this region are traders who sell fuel for small boats that cross the Musi River. Type 3 there is only one raft house that has a family relationship with parents' houses in the area of stilt houses facing each other. The relationships between physical and nonphysical in Type 3 is:

- Relationship between natural conditions and social cultural economic activities.

- Relationship between building types and natural conditions.

A raft house that adapts to river conditions. There are two units of raft houses in traditional settlements which currently construction of the building consists of bamboo and wooden poles so that the raft does not move. Besides that, the river is also the main orientation for the raft house which is on the Musi River because its livelihood depends on the Musi River.

Relationship of type of building with kinship. 


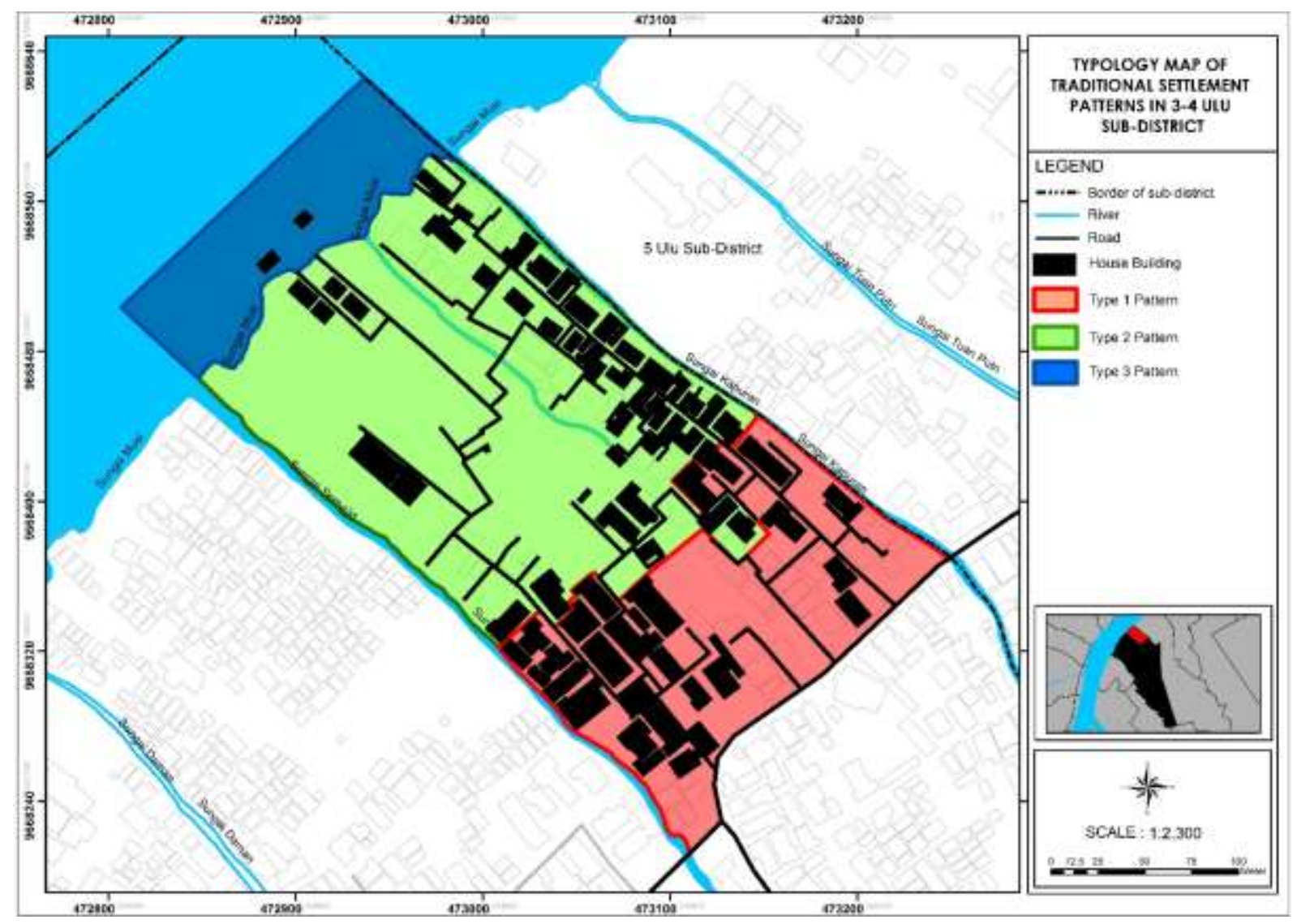

Fig. 2. Typology Map of Traditional Settlement Patterns in 3-4 Ulu Sub-District

\section{Outstanding Universal Value}

Outstanding universal value will discuss the relationship between physical and non-physical characteristics in traditional 3-4 Ulu Sub-District settlements. Based on the criteria of excellence in universal values, it can be seen that traditional settlements in 3-4 Ulu Sub-District have criteria, that are:

- Represent a masterpiece of human creative genius.

- Exhibit an important interchange of human values, over a span of time or within a cultural area of the world, on developments in architecture or technology, monumental arts, town-planning or landscape design.

- Be a unique or at least exceptional testimony to a cultural tradition or to a civilization which is living or which has disappeared.

- Be an outstanding example of a type of building, architectural or technological ensemble or landscape which illustrates a significant stage in human history.

- Be an outstanding example of a traditional human settlement, land-use, or sea-use which is representative of a culture (or cultures), or human interaction with the environment especially when it has become vulnerable under the impact of ireversible change.
- Be directly or tangibly associated with events or living traditions, with ideas, or with beliefs, with artistic and literary works of outstanding universal significance. (The Committee considers that this criterion should preferably be used in conjunction with other criteria).

- Contain superlative natural phenomena or areas of exceptional natural beauty and aesthetic importance.

Based on the preservation charter of the heritage city set by UNESCO, if a heritage has fulfilled one of ten criteria, then the object can be said to be a heritage area by UNESCO. Furthermore, the results of the outstanding universal value criteria will carry out protection and management to ensure the sustainability of the traditional 3-4 Ulu Sub-District settlements.

\section{Preservation of the Traditional Settlement Pattern}

Preservation will discuss the strategies for each typology of traditional 3-4 Ulu Sub-District settlement patterns with building and non-building conservation strategies. The relationship between building and nonbuilding preservation influences the strategy on the preservation of settlement patterns, because the 


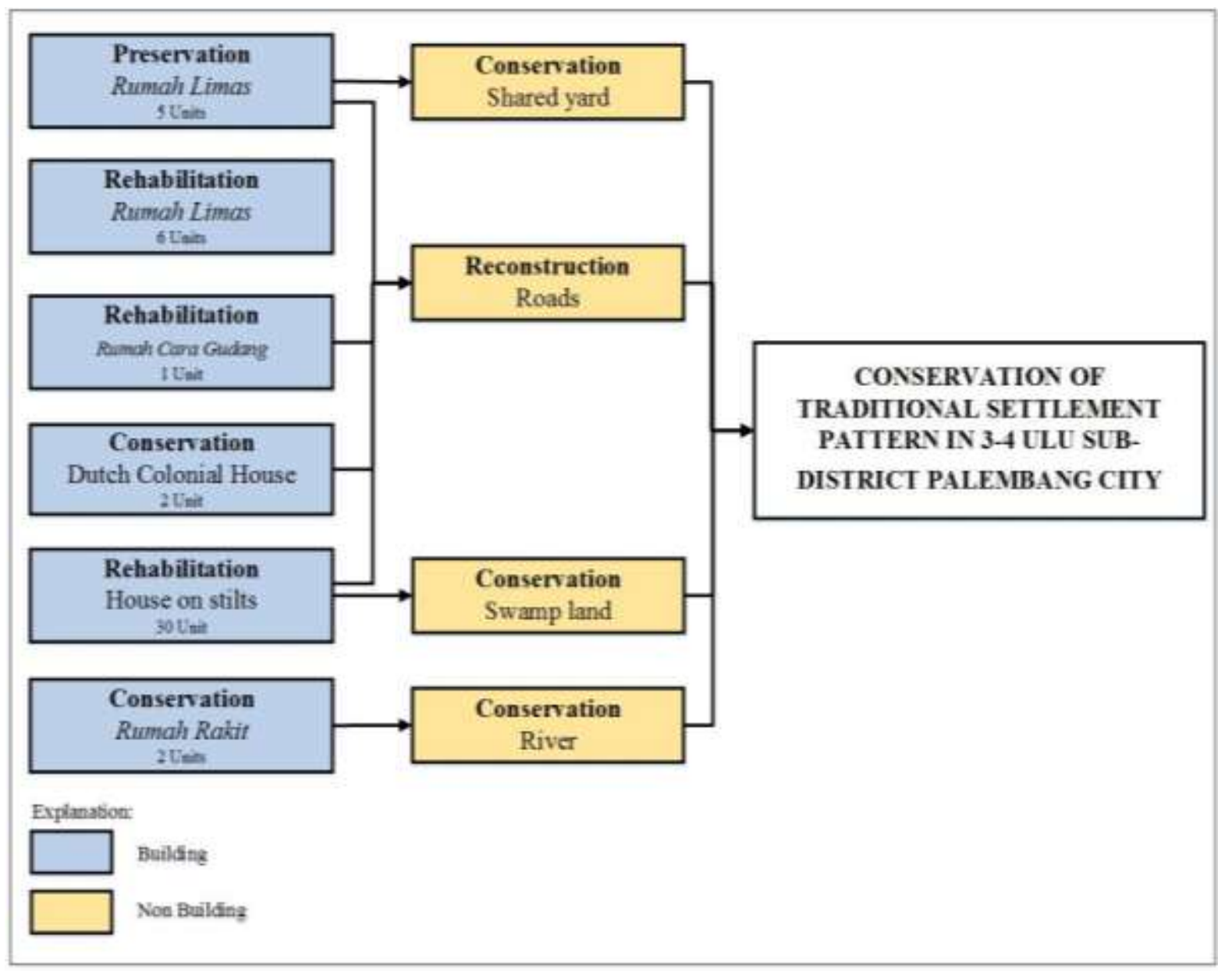

Fig. 3. Preservation Diagram of the Preservation of Traditional Settlement Patterns

variables of buildings and non-buildings are related to each other. These linkages are included in the strategy for non-physical activities such as social-cultural and economic uses of shared yard, roads, rivers and swamps to support social-cultural and economic activities.

Preservation of settlement patterns will discuss each conservation strategy which consists of presservation, conservation, rehabilitation and reconstruction. Potentially preserved objects are traditional houses, rivers, swamps, roads, and shared courtyards which aim to have cultural significance as a strategy for preservation in traditional settlements, but in nonbuilding objects do not carry out weighting calculations. The method in this analysis uses weighting scoring in accordance with the criteria in the research method, namely there are six criteria including aesthetics, extravagance, historical role, scarcity, greed, and strengthening the image of the region. Analysis results from calculations, namely:

- The potential object to be conserved is to produce the average value of the number of values of each object studied, namely 2 units Rumah Rakit, 1 unit
Rumah Cara Gudang, 19 units Rumah Limas, 51 units stilt houses, and 2 units Dutch colonial houses.

- Potential objects are dwellings that have values from six criteria of cultural significance below the average number of values of each type of object in traditional settlements.

\section{Preservation}

Preservation is an effort to preserve the built environment in accordance with its original conditions and prevent the process of damage. Determination preservation strategy calculation on the cultural significance of the object to be preserved. Preservation strategy applied to the pattern of Type 1 that consists of 5 units Rumah Limas. Preservation of the traditional house building will perform building maintenance strategies as follows (see figure 4).

\section{Conservation}

Conservation is all maintenance activities of a place to maintain its cultural value, while still using it 


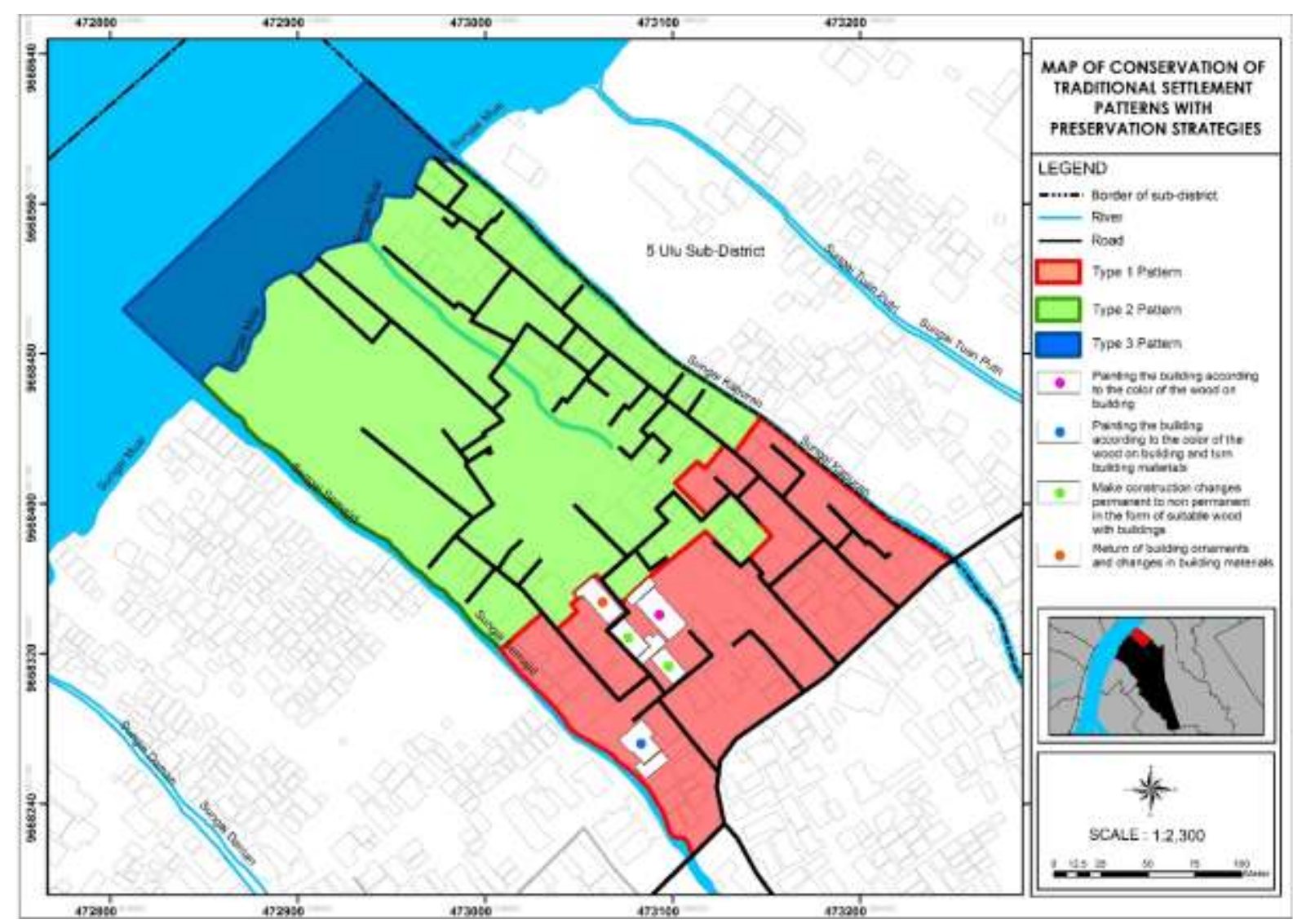

Fig. 4. Map of Conservation of Traditional Settlement Patterns with Preservation Strategies

to accommodate the same activities as the original or for new activities. Determination of conservation strategies is carried out calculation of cultural significance on the object to be preserved. The conservation strategy by conserving the face of the building will be carried out on Dutch architectural houses on Type 1 Patterns and Rumah Rakit on Type 2 Patterns. Conservation strategies are also carried out on nonbuildings including river, swamp, and shared yard areas. The condition of the river which is the object of the conservation strategy is the Musi River, especially the occupants of Rumah Rakit in traditional settlements. Conservation is done is not to change the orientation of Rumah Rakit. The function of the river is currently used by the public as transportation and economic space that must be maintained.

Swamp land uses a conservation strategy, because if swamp land is not considered it is feared that it will be stockpiled and used as new building land that will affect the characteristic functions of swamps in these traditional settlements, therefore minimizing the addition of new buildings in this area requires attention more specifically, because the traditional Palembang settlements that were left only in 3-4 Ulu Sub-District.
Preserving conservation on swamp land in traditional settlements is expected to maintain the condition of the original function of swamp land, both those used in daily activities or socio-cultural events.

The action in a shared yard is conservation, meaning that the shared yard is only allowed to change functions, for example in the daily activities of the shared yard used to hang clothes or activities of children playing. The function of land when sociocultural activities such as the traditional Palembang wedding ceremony, editing, and the event of death, this land is used to accommodate guests if the capacity at home is sufficient. Conservation strategies for buildings and non-buildings will take the following maintenance measures (see figure 5).

- Painting the building according to the type of construction in the building.

- Change building materials in the event of damage or weathering.

- Maintain the original function of the Musi River.

- Maintain the function of swamp land in daily activities, socio-cultural and economic activities.

- Maintain the original function of the shared yard, which is as a place of socialization and additional space when socio-cultural activities. 


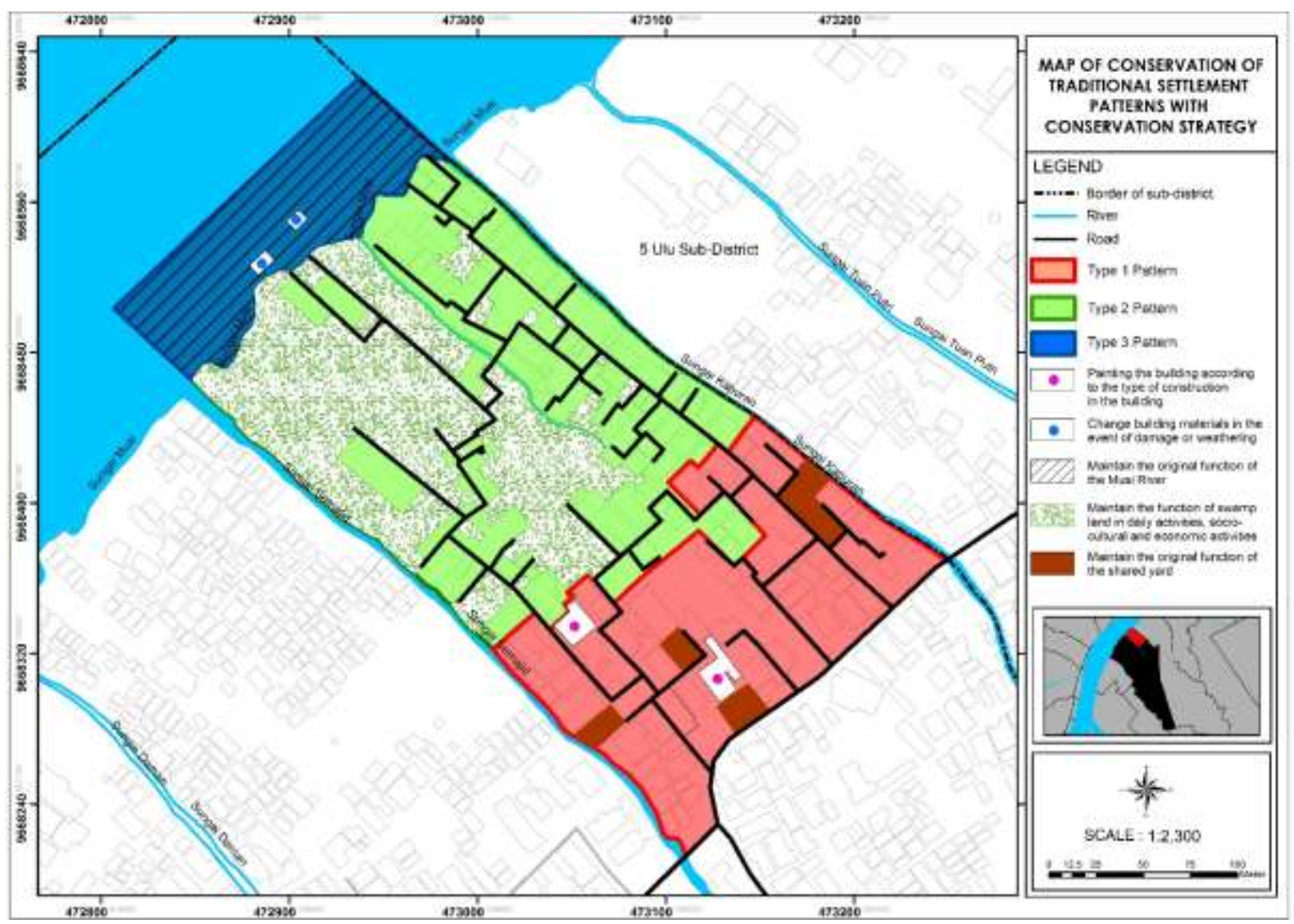

Fig. 5. Map of Conservation of Traditional Settlement Patterns with Conservation Strategy

Building painting activities are carried out on buildings with less damage as in Dutch architectural houses. The Dutch architecture house is still maintained and the (owner) of the house often paints the house when it looks dull. While the Rumah Rakit paint and change building materials, because Rumah Rakit that are above the Musi River and are often affected by river water cause Rumah Rakit to experience weathering due to insects or mosses.

\section{Rehabilitation}

The definition of rehabilitation is to restore the condition of a building that has been damaged or decreased, so that it can function again as usual. Determining the rehabilitation strategy is carried out by calculating the cultural significance of the object to be preserved. Rehabilitation is carried out on Type 1 and Type 2 patterns of traditional settlement typologies. The rehabilitation strategy for building traditional houses will carry out building maintenance actions as follows (see figure 6).

- Carry out rehabilitation actions on buildings with original materials, if not available as the original material, then similar material can be used to repair the Rumah Cara Gudang, stage house and Rumah Rakit.
- Repair of building construction that has been damaged or weathered.

- Painting the building according to the color of the wood in the building.

Rehabilitation activities are carried out on houses that are constructed of wood such as houses for storing pyramid houses, and houses on stilts. These buildings were established in accordance with the conditions of the land in traditional settlements. The type of soil in traditional settlements is dominated by swamp land and when tides, river water enters into the area until it makes the roads in the settlement corridor inundated. Therefore, rehabilitation activities are needed to treat house buildings such as changing the construction of rotten buildings and painting if the building looks dull.

\section{Reconstruction}

Efforts to restore conditions or rebuild as closely as possible with the original known appearance. Elements of traditional settlements that require a reconstruction strategy are roads. Roads used by the community have important values in addition to mobilizing daily activities, but are also used as rituals when traditional events. 


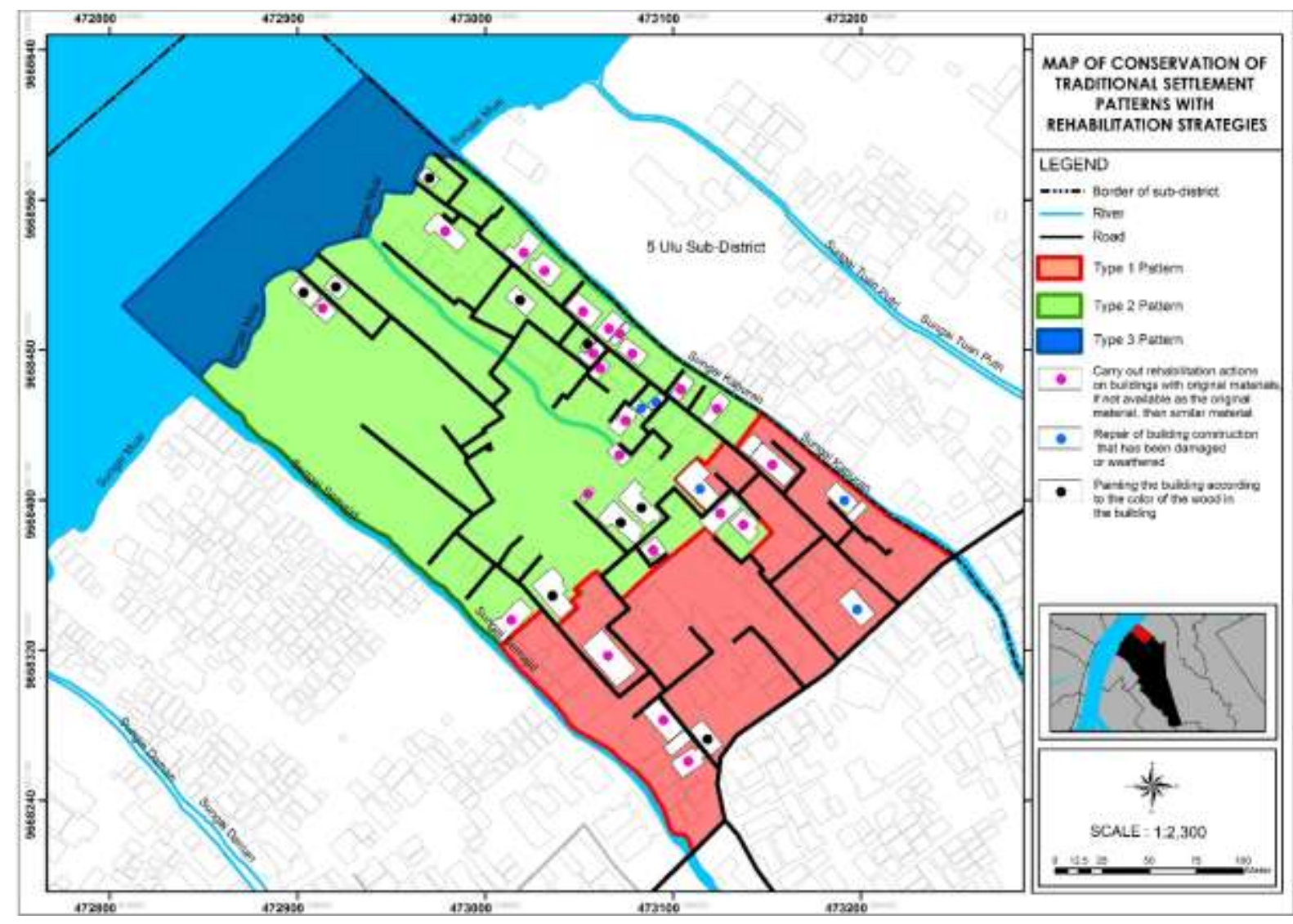

Fig. 6. Rehabilitasi Map of Conservation of Traditional Settlement Patterns with Rehabilitation Strategies

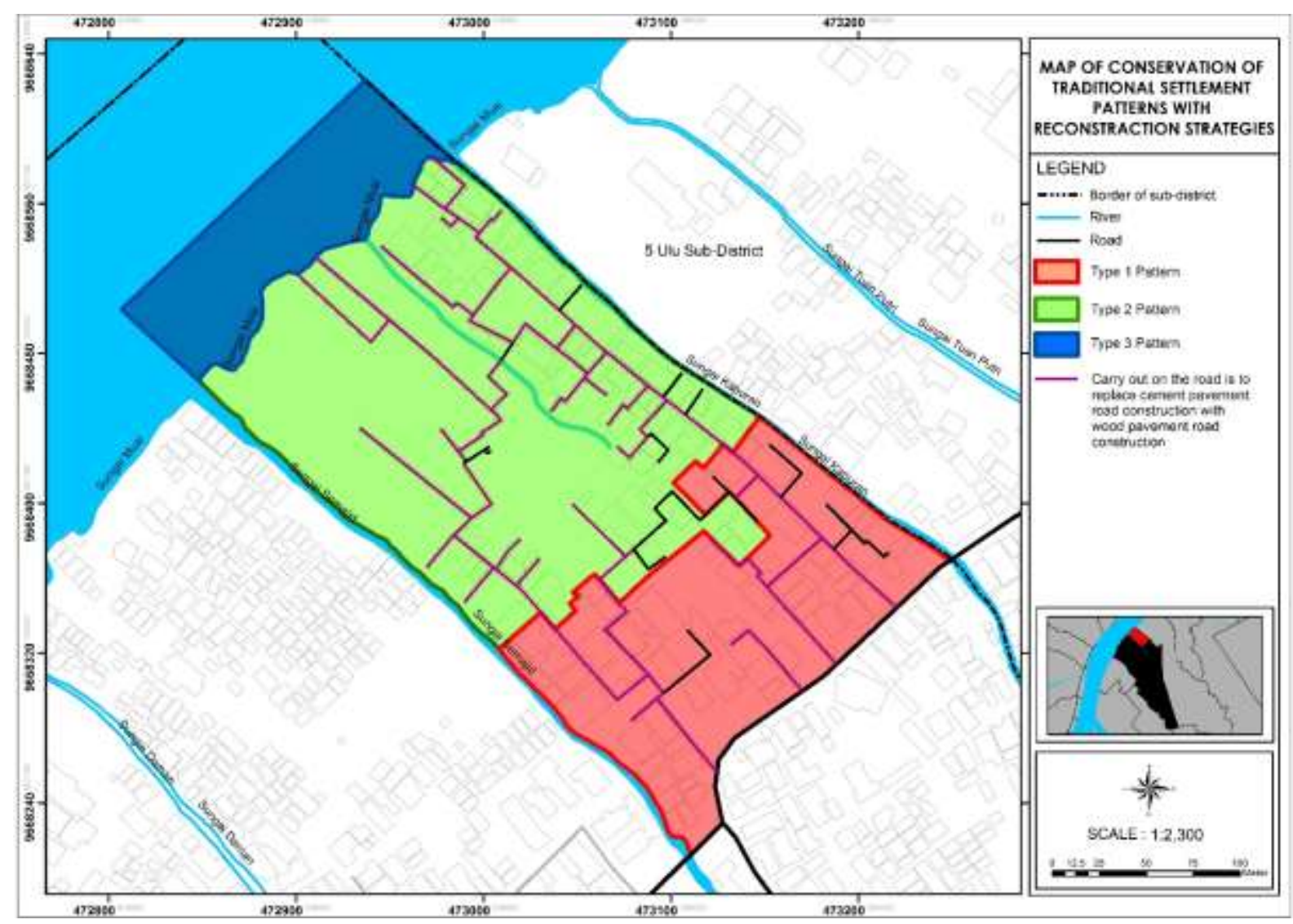

Fig. 7. Map of Conservation of Traditional Settlement Patterns with Reconstruction Strategies 
The strategy to be carried out on the road is to replace cement pavement road construction with wood pavement road construction, because wood construction is more suitable for use in wet or waterlogged soils and is also stronger and durable than cement construction which is less flexible to water submerged soil conditions.

\section{CONCLUSION}

Traditional settlement patterns have three types of patterns, the three types are obtained from the results of overlaying maps of physical and nonphysical conditions that are related to each other. These interrelationships include building and kinship, building types and natural conditions, building types and social-cultural, network and social cultural, network and natural conditions, natural and socialcultural economic conditions, building types and kinship. Conservation in the traditional 3-4 Ulu SubDistrict strategy is to preserve preservation, conservation, rehabilitation and reconstruction of buildings, roads, shared yards, swamps, and river areas utilized by the community. Based on the analysis found that the preservation actions carried out at five houses. Conservation actions are carried out on four housing units, swamps, river areas, and shared yard. Rehabilitation measures for 37 housing units and reconstruction actions on roads in the Lorong Firm H. Akil and Lorong Hijriyah.

\section{REFERENCES}

Asikin, D., Antariksa, Wulandari, D. I., \& Rukmi, W. I. (2017). Spatial adaptation as the Madurese migrant resilience form at urban informal sector workers settlement: a case study of Kotalama settlement - Malang. IOP Conf. Series: Earth and Environmental Science.

Cesain B. T., \& Ginting, C. (2015). Persepsi Masyarakat terhadap Permukiman Bantaran Sungai. Teтu Ilmiah IPLBI.

Handayani, D. U. N., Soelistijadi R., \& Sunardi. (2005). Pemanfaatan Analisis Spasial untuk Pengolahan Data Spasial Sistem Informasi Geografi. Jurnal Teknologi Informasi DINAMIK, 10(2).

Lussetyowati, T. (2012). Peninggalan Arsitektur di Tepian Sungai Musi. Palembang: Sriwijaya University.

Maulidi C., \& Wulandari L.D. (2017). Changing cultural landscape in post-productivism of rice field in Nyuh Kuning Village Bali. 3rd International Conference of Planning in the Era of Uncertainty. Malang: University of Brawijaya.

Permatasari, I., Antariksa, \& Rukmi, W. I. (2008). Permukiman Perdesaan di Desa Trowulan Kecamatan Trowulan Kabupaten Mojokerto. Arsitektur e-journal, 1(2).

Sasongko, I. (2005). Harmonisasi Tata Ruang Permukiman Melalui Mitos (Studi Kasus: Permukiman Sasak Desa Puyung). Jurnal Plannit, $3(2)$.

Sasongko, I. (2005). Struktur Ruang Permukiman Karangsalah dan Segenter di Desa Bayan. Jurnal Dimensi Teknik Arsitektur, 20(1), 16-25. 